\title{
Lymphocyte subpopulations in donovanosis assessed by monoclonal antibodies and immunoglobulins
}

\author{
V N SEHGAL,* M K JAIN,* V K SHARMA $\dagger$ \\ From the Departments of *Dermatology and Venereology and $\nmid$ Microbiology, Maulana Azad Medical College \\ and Associated LNJPN and GB Pant Hospitals, New Delhi, India
}

SUMMARY The haematological profile and peripheral blood lymphocyte subpopulations of 36 patients with donovanosis were estimated by an indirect immunofluorescence technique using monoclonal antibodies. Concentrations of serum immunoglobulins (IgM, IgG, and IgA) were also estimated. The total leucocyte and lymphocyte counts were generafly raised, as were total T lymphocyte, T4, and T8 counts. Patients with the hypertrophic variant, however, had decreased numbers of T lymphocytes and T8 cells and increased B cells and IgG. B lymphocyte counts and IgM and IgG concentrations were raised generally.

The epidemiological and clinical characteristics of donovanosis in areas where it is endemic ${ }^{12}$ or nonendemic ${ }^{3}$ are now well documented. Its pathogenesis, however, remains largely unknown, and its prime location in the genital region is intriguing. Tissue responses are local initially, but histopathology does not yield information about its pathogenesis. This study was undertaken to elucidate some aspects of the immune response of people with donovanosis.

\section{Patients and methods}

We investigated 36 patients with donovanosis, comprising 27 with ulcerogranulomatous, seven with hypertrophic, and two with sclerotic variants. The diagnosis in each case was made on the basis of the clinical features ${ }^{3}$ and Giemsa stained tissue smears. Diagnoses were confirmed by the characteristic histopathology ${ }^{4}$ and by showing Donovan bodies in slow (overnight) Giemsa stained tissue sections. A thorough general physical examination was undertaken to exclude concomitant disease.

We estimated the lymphocyte subpopulations ( $T$ and B lymphocytes, T4 subset (helper/inducer) and T8 subset (cytotoxic/suppressor) lymphocytes) in heparinised blood using monoclonal mouse antihuman antibodies (Dakopatts Company, Denmark)

Address for correspondence/ Professor V N Sehgal, A/6 Panchwati, Delhi-110 033, India

Accepted for publication 8 November 1986 in an indirect immunofluorescence method. ${ }^{5}$ We estimated the total and differential leucocyte count in heparinised blood to obtain the percentage and absolute counts of lymphocytes.

We separated the lymphocytes from the heparinised blood by gradient centrifugation using Histopaque solution (Sigma) containing Ficoll Hypaque $400(57 \mathrm{~g} / \mathrm{l})$ and sodium diatrizoate $(90 \mathrm{~g} / \mathrm{l}){ }^{6}{ }^{6}$ The viability of lymphocytes was checked with trypan blue, and more than $90 \%$ of the cells were viable. A final cell suspension of $1-10 \times 10^{9} / 1$ was obtained, and $100 \mu \mathrm{l}$ of this suspension was centrifuged for five minutes at $100 \times g$. The cell pellet was resuspended in Hank's balanced salt solution, and $50 \mu \mathrm{l}$ of specific monoclonal antibody (at a dilution of $1 / 10$ ) was added and incubated. The lymphocytes were then washed twice and the lymphocyte suspension was mixed with $30 \mu$ l fluorescein conjugated (rabbit) antimouse immunoglobulin (Dakopatts, Denmark, F-232) diluted $1 / 16$. After being incubated at $4^{\circ} \mathrm{C}$ for 30 minutes, the suspension was washed twice with Hank's balanced salt solution. Evans blue dye $(1 / 30000)$ was used to counterstain. The cells were finally washed and resuspended in $10 \mu$ l washing medium and an equal volume of buffered glycerol. A drop of suspension was placed on a microslide, covered with a coverslip, and sealed with nail polish. The slide was examined under an epi-illumination fluorescent microscope with relevant excitation and barrier filters applied.

We counted a total of 100 lymphocytes as shown by apple green fluorescence. We estimated the lymphocyte subpopulation as a percentage of all lymphocytes. We then calculated the absolute value in each 
case by multiplying the percentage by absolute lymphocyte counts.

We measured serum IgM, IgG, and IgA concentrations by radial immunodiffusion using limit diffusion in agar gel $^{7}$ on "Tripartigen plates" (Hoechst Pharmaceuticals, Bombay, India). Undiluted sera were used to estimate IgA and IgM, whereas the sera were diluted 10 times with isotonic saline to measure IgG concentrations. Standard control serum provided by Hoechst Pharmaceuticals was used to calibrate immunoglobulin concentrations.

Student's $t$ test was used for statistical evaluation.

\section{Results}

Table 1 shows that patients with ulcerogranulomatous donovanosis of less than three months' duration had significantly $(\mathrm{t}=2.4, \mathrm{p}<0.05)$ increased total leucocyte counts, whereas the difference was not significant in patients who had had the disease longer or had other variants of it.

In patients with the ulcerogranulomatous variant of shorter duration, the $T$ cell count was significantly $(\mathrm{t}=2.7, \mathrm{p}<0.02)$ increased (table 2). Patients with the hypertrophic variant, however, had increases in
T4 cells and decreases in T lymphocytes and T8 cells, but these differences from control values were not significant. Table 2 also shows the absolute counts of B lymphocytes according to the duration of clinical variants. The increase in B lymphocytes in patients with the ulcerogranulomatous and hypertrophic variants of donovanosis was not significant.

Table 3 shows alterations in concentrations of serum immunoglobulins in patients with variants of donovanosis. The IgG concentrations were significantly raised in patients with the ulcerogranulomatous variant of longer duration $(t=6.8$, $p<0.01)$ and those with the hypertrophic variant of longer duration $(t=6.5, p<0.01)$. Other changes were not significant.

\section{Discussion}

All patients with donovanosis showed an overall increase in leucocyte counts irrespective of the duration and clinical variants of the disease. Differential lymphocyte counts and numbers of $T$ lymphocytes were also raised. As T lymphocytes are heterogenous populations of several cell types, the

Table 1 Basic haematolagical profile of patients with one of three clinical variants of donovanosis of less or more than three months' duration

\begin{tabular}{|c|c|c|c|c|}
\hline \multirow[b]{2}{*}{ Biagnosis and duration } & \multicolumn{2}{|c|}{ Total leucocyte count $\left(\times 10^{9} / \mathrm{l}\right)$} & \multicolumn{2}{|c|}{ Differential lymphocyte count $\left(\times 10^{9} / l\right)$} \\
\hline & $\operatorname{Mean}(S D)$ & Range & $\operatorname{Mean}(S D)$ & Range \\
\hline Controls & $6.5(1.4)$ & 4.4-9.0 & $2 \cdot 1(0.9)$ & $0.9-3.9$ \\
\hline $\begin{array}{l}\text { Ulcerogranulomatous: } \\
\text { Up to } 3 \text { months } \\
\text { Over } 3 \text { months }\end{array}$ & $\begin{array}{l}8.3(2.8) \\
5.5(0.9)\end{array}$ & $\begin{array}{l}4 \cdot 9-12 \cdot 4^{*} \\
4 \cdot 6-6 \cdot 3\end{array}$ & $\begin{array}{l}2 \cdot 7(0.9) \\
2 \cdot 1(0.7)\end{array}$ & $\begin{array}{l}1 \cdot 4-4 \cdot 2 \\
1 \cdot 7-2 \cdot 9 * *\end{array}$ \\
\hline $\begin{array}{l}\text { Hypertrophic: } \\
\text { Over } 3 \text { months only }\end{array}$ & $6.9(2.4)$ & $4 \cdot 4-10 \cdot 6$ & $2 \cdot 2(1 \cdot 1)$ & $0 \cdot 9-4 \cdot 0$ \\
\hline $\begin{array}{l}\text { Sclerotic: } \\
\text { Under } 3 \text { months only }\end{array}$ & $7 \cdot 5(2 \cdot 1)$ & $6 \cdot 0-9 \cdot 0$ & $2.4(0.5)$ & $2 \cdot 0-2 \cdot 7$ \\
\hline
\end{tabular}

${ }^{*} \mathrm{p}<0.05 ;{ }^{* *} \mathrm{p}<0.02$.

Table 2 Absolute counts of $T$ lymphocytes, their T4 and T8 subsets, and B lymphocytes in patients with one of three clinical variants of donovanosis of less or more than three months' duration

\begin{tabular}{|c|c|c|c|c|c|c|c|c|}
\hline \multirow[b]{2}{*}{ Diagnosis and duration } & \multicolumn{2}{|c|}{ Tlymphocytes } & \multicolumn{2}{|l|}{ T4 subsets } & \multicolumn{2}{|l|}{ T8 subsets } & \multicolumn{2}{|c|}{ B lymphocytes } \\
\hline & $\operatorname{Mean}(S D)$ & Range & $\operatorname{Mean}(S D)$ & Range & $\operatorname{Mean}(S D)$ & Range & Mean $(S D)$ & Range \\
\hline $\begin{array}{l}\text { Controls } \\
\text { Ulcerogranulomatous: }\end{array}$ & $1261(618)$ & $616-2730$ & $726(346)$ & $319-1560$ & 489 (217) & $197-975$ & $356(160)$ & $160-713$ \\
\hline $\begin{array}{l}\text { Up to } 3 \text { months } \\
\text { Over } 3 \text { months } \\
\text { Hypertrophic: }\end{array}$ & $\begin{array}{l}1798(614) \\
1551(425)\end{array}$ & $\begin{array}{c}855-3120^{*} \\
1216-2029\end{array}$ & $\begin{array}{l}950(336) \\
727(94)\end{array}$ & $\begin{array}{l}428-1914 \\
561-811\end{array}$ & $\begin{array}{l}631(229) \\
454(100)\end{array}$ & $\begin{array}{l}271-1082 \\
348-546\end{array}$ & $\begin{array}{l}397(203) \\
462(294)\end{array}$ & $\begin{array}{l}178-930 \\
166-753\end{array}$ \\
\hline $\begin{array}{l}\text { Over } 3 \text { months only } \\
\text { Sclerotic: }\end{array}$ & $536(754)$ & $581-2618$ & 779 (269) & $308-1208$ & $472(224)$ & $176-806$ & $499(302)$ & $176-1008$ \\
\hline Under 3 months only & 1068 (399) & $1326-1890$ & $779(120)$ & $694-864$ & $681(183)$ & $551-810$ & 349 (118) & $265-432$ \\
\hline
\end{tabular}

$* t=2.65, p<0.02$ 
Table 3 Serum immunoglobulin concentrations in patients with one of three clinical variants of donovanosis of less or more than three months' duration

\begin{tabular}{|c|c|c|c|c|c|c|}
\hline \multirow[b]{2}{*}{ Diagnosis and duration } & \multicolumn{2}{|l|}{$\operatorname{Ig} M(g / l)$} & \multicolumn{2}{|l|}{$\operatorname{Ig} G(g / l)$} & \multicolumn{2}{|l|}{$\operatorname{Ig} A(g / l)$} \\
\hline & $\operatorname{Mean}(S D)$ & Range & $\operatorname{Mean}(S D)$ & Range & $\operatorname{Mean}(S D)$ & Range \\
\hline $\begin{array}{l}\text { Controls } \\
\text { Ulcerogranulomatous: }\end{array}$ & $1.6(0 \cdot 5)$ & $1 \cdot 1-2 \cdot 9$ & $12 \cdot 7(1.9)$ & $9 \cdot 7-16 \cdot 0$ & $2 \cdot 3(0 \cdot 7)$ & $1.4-3.5$ \\
\hline $\begin{array}{l}\text { Up to } 3 \text { months } \\
\text { Over } 3 \text { months }\end{array}$ & $\begin{array}{l}1.8(0.6) \\
2.4(0.4)\end{array}$ & $\begin{array}{l}0.8-3 \cdot 2 \\
2 \cdot 0-2 \cdot 8\end{array}$ & $\begin{array}{l}15.3(3.9) \\
20.6(1.0)\end{array}$ & $\begin{array}{c}8 \cdot 6-19 \cdot 8 \\
19 \cdot 8-21 \cdot 8^{*}\end{array}$ & $\begin{array}{l}2 \cdot 2(0 \cdot 9) \\
2 \cdot 2(0 \cdot 4)\end{array}$ & $\begin{array}{l}0.9-3.5 \\
1.8-2.6\end{array}$ \\
\hline $\begin{array}{l}\text { Hypertrophic: } \\
\text { Over } 3 \text { months only } \\
\text { Sclerotic: }\end{array}$ & $1.7(0.8)$ & $0.7-2.9$ & $20 \cdot 3(3 \cdot 6)$ & $15 \cdot 1-25 \cdot 8^{*}$ & $2.3(0.8)$ & $0.9-3.4$ \\
\hline Under 3 months only & $1 \cdot 6(0 \cdot 1)$ & $1.5-1.6$ & $15 \cdot 5(6 \cdot 0)$ & $11 \cdot 3-19 \cdot 8$ & $3 \cdot 0(0 \cdot 7)$ & $2 \cdot 6-3 \cdot 5$ \\
\hline
\end{tabular}

${ }^{*} \mathrm{p}=0.001$.

subpopulations of these cells probably play a part in the disease.

In healthy people the ratio of $\mathrm{T} 4$ to $\mathrm{T} 8$ cells is usually 1.5 to $2 .^{8}$ In our study, T4 cell numbers were raised in all the patients. Similarly, there was an increase in the numbers of T8 cells. The ratio of T4 to T8 cells was therefore maintained. Absolute counts of T4 and T8 cells were also raised in all the ulcerogranulomatous patients.

The absolute numbers of B lymphocytes were raised, with a corresponding increase in IgM and IgG. Such an increase of counts of B lymphocytes, and elevation of serum IgG concentrations was a feature in the hypertrophic variant.

The variables reported here, complemented by future studies of the distribution of $T$ cell subsets and immunoglobulin synthesising B cells in the tissue, may elucidate further the pathogenesis of donovanosis.

\section{References}

1 Anonymous. Non-gonococcal urethritis and other selected sexually-transmitted diseases of public health importance. WHO Tech Rep Ser; No 660:1-142.

2 Sehgal VN, Shyam Prasad AL. Donovanosis: current concepts. Int J Dermatol 1986;25:8-16.

3 Sehgal VN, Prasad ALS. A clinical profile of donovanosis in a non-endemic area. Dermatologica 1984;168:273-8.

4 Sehgal VN, Prasad ALS, Beohar PC. Histopathological diagnosis of donovanosis. British Journal of Venereal Diseases 1984;60:45-7.

5 Reinherz EL, Kung PC, Goldstein G, Schlossman SF. Separation of functional subsets of human T-cells by monoclonal antibody. Proc Natl Acad Sci USA 1979;76:4061-5.

6 Boyam A. Separation of leucocytes from blood and bone marrow. Scand J Clin Lab Invest 1968;21:9-89.

7 Mancini G, Carbonara AC, Hareman JP. Immunological quantitation of antigens by single radial immunodiffusion. Immunochemistry 1965;2:235-54.

8 Yatchie A, Miyawaki T, Nagaoki T. Regulation of Bdifferentiation by T-cell subsets defined with monoclonal OKT4 and OK-T8 antibodies in human cord blood.J Immunol 1981;127:1314-7. 